\title{
ISOLATION AND CHARACTERIZATION OF PROTEIN FRACTIONS ISOLATED FROM CAMELINA MEAL
}

\author{
N. Li, G. Qi, X. S. Sun, D. Wang, S. Bean, D. Blackwell
}

\begin{abstract}
Camelina is a new oil crop in North America. Camelina meal, a by-product of the camelina oil extraction process, typically contains $10 \%$ to $15 \%$ residual oil and $40 \%$ crude protein. As camelina oil demand increases, utilization of camelina protein for value-added products is critical to food and biotechnology industries; however, few studies have been conducted on camelina proteins. In this study, camelina protein fractions (albumin, globulins, and glutelins) were isolated from camelina meal based on their solubility using three different sequences: method 0 (S0), method 1 (S1), and method 2 (S2). The proteins' physicochemical properties, including solubility, amino acid profiles, molecular weight, and thermal and morphological properties, were also characterized. Results showed that S1 harvested more protein (88.20\%) than SO (84.05\%) and S2 (76.52\%). Glutelin was the major fraction (64.64\%) in camelina, followed by globulin (17.67\%), and albumin (10.54\%). Essential amino acids accounted for approximately $40 \%$ of the total amino acids in camelina protein. High molecular weight aggregates stabilized by covalent bonds in the glutelin and albumin fractions, as shown in size-exclusion chromatography (SEC), are closely related to larger-size protein aggregates observed in TEM images.
\end{abstract}

Keywords. Albumin, Amino acid profiles, Camelina protein, FTIR, Globulin, Glutelin, Molecular weight, SEC, TEM, $T G A$.

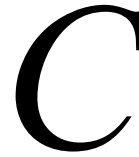
amelina sativa, also known as camelina, gold-ofpleasure, false flax, wild flax, linseed dodder, or German sesame, is an important and ancient oil plant that originated in Germany around 600 B.C. (Budin et al., 1995). In North America, camelina is a new oil crop that was possibly introduced as a weed in flax. Camelina is an annual summer or wintering plant with a short mature period (85 to 100 days) (Budin et al., 1995; Sampath, 2009).

In general, camelina contains $29.9 \%$ to $38.3 \%$ oil, $23 \%$ to $30 \%$ protein, $10 \%$ carbohydrates, and $6.6 \%$ ash, depending on the variety and variations of soil composition and environment (Budin et al., 1995; Sampath, 2009). Camelina oil contains up to $90 \%$ unsaturated fatty acid, of which approximately $33.6 \%$ is $\alpha$-linolenic acid (18:3, omega- 3 ), which is lower than flaxseed $(45.1 \%)$ but far exceeds cano-

Submitted for review in October 2013 as manuscript number FPE 10455; approved for publication by the Food \& Process Engineering Institute of ASABE in January 2014. Presented at the 2012 ASABE Annual Meeting as Paper No. 131591989.

Mention of company or trade names is for description only and does not imply endorsement by the USDA. The USDA is an equal opportunity provider and employer.

The authors are Ningbo Li, ASABE Member, Graduate Research Assistant, Department of Biological and Agricultural Engineering, Guangyan Qi, Postdoctoral Fellow, Department of Grain Science and Industry, Xiuzhi Susan Sun, ASABE Member, Distinguished Professor, Department of Grain Science and Industry, and Donghai Wang, ASABE Member, Professor, Department of Biological and Agricultural Engineering, Kansas State University, Manhattan, Kansas; Scott Bean, Research Chemist, and Deidre Blackwell, Postdoctoral Fellow, USDAARS Center for Grain and Animal Health Research, Manhattan, Kansas. Corresponding author: Donghai Wang, 150 Seaton Hall, Kansas State University, Manhattan, KS 66506; phone: 785-532-2919; e-mail: dwang @ksu.edu. la $(6.6 \%)$, soybean $(7.2 \%)$, and sunflower $(0 \%)$ (Budin et al., 1995). The high omega-3 content in camelina offers an opportunity to meet the growing demand for good-quality edible oils. Camelina oil also shows great potential as a source of biodiesel; in particular, it can be used to produce jet fuels that reduce greenhouse gas emissions up to $80 \%$ compared to petroleum-based jet fuel (Shonnard et al., 2010). Camelina meal is a by-product of the oil extraction process from camelina seed that typically contains $10 \%$ to $15 \%$ residual oil, $40 \%$ crude protein, $5 \%$ minerals, $10 \%$ to $12 \%$ crude fiber, and a small portion of vitamins (Sampath, 2009). As edible oil demands and biodiesel production increase, utilization of camelina protein for value-added products is critical to food and biotechnology industries.

Compared with other oilseeds such as canola, flaxseed, or soybean, camelina is less investigated for its protein research. However, protein isolation technologies applied to other oil seeds provided a framework for recovering proteins from camelina. According to previous studies, oilseeds usually contain mixed or heterogeneous proteins comprising different protein fractions (Manamperi et al., 2008; Ayad, 2010). Manamperi et al. (2008) isolated four protein fractions from canola meal based on protein solubility at different $\mathrm{pH}$ : albumins (water-soluble), globulins (5\% NaCl-soluble), prolamins (70\% ethanol-soluble), and glutelins $(0.1 \mathrm{~N} \mathrm{NaOH}$-soluble). Results showed a protein recovery rate of $78.6 \%$, among which albumins were the major fraction (38.7\%), followed by globulins $(22.0 \%)$, glutelins $(10.3 \%)$, and prolamins $(7.6 \%)$. These protein fractions were characterized by varied functional properties. Prolamins showed higher fat absorption, whereas globulins were characterized by better emulsifying activity. Ayad (2010) isolated flaxseed protein fractions from defat- 
ted flaxseed meal, and $38.1 \%$ albumin, $27.9 \%$ globulin, and $22.5 \%$ glutelin were extracted.

Camelina proteins are a mixture of protein fractions including albumins, globulins, and glutelins with varied solubility. Research on isolation and characterization of camelina protein fractions has not been reported. Therefore, the objective of this research was to study isolation processes for camelina protein fractions and to characterize the proteins' physicochemical properties, including solubility, morphological characteristics, and thermal properties, as well as amino acid profiles.

\section{MATERIALS AND METHODS MATERIALS}

Camelina meal (CM) with 15\% lipids (d.b.), 32.4\% crude protein (d.b.), and $11.0 \%$ moisture content (w.b.) was provided by Montana Gluten-Free Processors (Belgrade, Mont.). Meal pellets emerged from a screw oil press at approximately $80^{\circ} \mathrm{C}$. Hexanes, Bradford assay kit, hydrochloric acid $(\mathrm{HCl})$, and sodium hydroxide $(\mathrm{NaOH})$ were purchased from Fisher Scientific (Fair Lawn, N.J.).

\section{Camelina Meal Defatting}

Camelina meal with particle size $<0.5 \mathrm{~mm}$ was obtained by using a cyclone sample mill (Udy Corp., Fort Collins, Colo.). Camelina meal was then defatted with hexane at a solid/liquid ratio of 1:10 $(\mathrm{w} / \mathrm{v})$ for $2 \mathrm{~h}$ at room temperature in three cycles. The defatted camelina meal (DCM) was placed in a fume hood with a very thin layer $(\sim 2 \mathrm{~mm})$ for $24 \mathrm{~h}$ to evaporate residual hexane.

\section{MAXIMUM SOLUBILITY PH OF GLUTELIN}

A standard curve was created first. Standard protein solutions were prepared using $0,0.10,0.25,0.50,0.75$, and $1.00 \mathrm{mg}$ protein $\mathrm{mL}^{-1}$ bovine serum albumin (BSA), and absorption readings of the solutions were measured with a BioMate 3 UV-Vis spectrophotometer (Madison, Wisc.) at $595 \mathrm{~nm}$. The readings and known protein concentrations were interpolated in the calibration curve, and the standard curve was used to determine protein concentration in solutions tested in this study by spectrophotometer readings. The standard curve was reliable only in the range from 0.0 to $1.0 \mathrm{mg} \mathrm{mL}^{-1}$ of protein, and protein contents of the samples studied in this part of the experiment remained in this range.

Based on a preliminary test to determine the $\mathrm{pH}$ at which camelina glutelin protein has maximum solubility, $10 \mathrm{~g}$ of DCM was dispersed in $1000 \mathrm{~mL}$ of distilled water for $1 \mathrm{~h}$. The slurry was then adjusted to a $\mathrm{pH}$ of 10 using $2 \mathrm{~N} \mathrm{NaOH}$ and continuously stirred for $2 \mathrm{~h}$. Five milliliters of the slurry was collected and centrifuged at $12,000 \times \mathrm{g}$ for $15 \mathrm{~min}$, and then the supernatant was decanted through a six-layer cheesecloth to remove impurities. All centrifugation conditions mentioned in this article were identical unless otherwise indicated. The remaining slurry was adjusted to $\mathrm{pH} 10.5,11.0,11.5,12.0,12.5$, and 13.0 with $2 \mathrm{~N}$ $\mathrm{NaOH}$, respectively, and then stirred for $2 \mathrm{~h}$. Slurry samples were collected and centrifuged at each $\mathrm{pH}$ point. At the specified $\mathrm{pH}$ points, $100 \mu \mathrm{L}$ of the supernatant was mixed with $3 \mathrm{~mL}$ of Bradford reagent for $10 \mathrm{~min}$ at room temperature, and absorbance of the solution was measured with the BioMate 3 spectrophotometer at $595 \mathrm{~nm}$. Each sample was measured in triplicate.

\section{Solubilities of Camelina Protein Fractions}

Glutelin: $10 \mathrm{~g}$ of DCM was dispersed in $1,000 \mathrm{~g}$ of distilled water with $\mathrm{pH}$ adjusted to 12 using $2 \mathrm{~N} \mathrm{NaOH}$. The slurry was stirred for $2 \mathrm{~h}$ and then centrifuged. The $\mathrm{pH}$ of the supernatant dropped from 12 to 1.0 in increments of 0.5 . Slurry samples were collected and centrifuged at each $\mathrm{pH}$ point, and the supernatants were used to measure protein content.

Albumin: $10 \mathrm{~g}$ of DCM was mixed with $500 \mathrm{~g}$ of distilled water for $2 \mathrm{~h}$, with stirring followed by centrifugation. The $\mathrm{pH}$ of the supernatant initially dropped to 6.0 and then dropped from 6.0 to 1.0 in increments of 0.5 with $\mathrm{pH}$ adjusted using $2 \mathrm{~N} \mathrm{HCl}$. Slurry samples were collected and centrifuged at each $\mathrm{pH}$ point, and the supernatants were used to measure protein content.

Globulin: $10 \mathrm{~g}$ of DCM was mixed with $500 \mathrm{~g}$ of $5 \%$ $\mathrm{NaCl}$ solution for $2 \mathrm{~h}$, and the slurry was stirred and centrifuged. The $\mathrm{pH}$ of the supernatant initially dropped to 6.0 and then dropped from 6.0 to 1.0 in increments of 0.5 with $\mathrm{pH}$ adjusted using $2 \mathrm{~N} \mathrm{HCl}$. Slurry samples were collected and centrifuged at each $\mathrm{pH}$ point, and the supernatants were measured protein content.

\section{Isolation of Camelina Protein Fractions}

Method 0 (S0): With this method, globulin 0 and glutelin 0 were isolated from two batches of DCM with the same solvents and centrifugation procedures as described for S1, respectively, without a degumming step.

Method 1 (S1): Protein can be fractionated into albumins, globulins, glutelins, and prolamins with different solvents (Osborne, 1924). Based on the preliminary testing, three protein fractions (albumin, globulin, and glutelin) were isolated with distilled water, $5 \% \mathrm{NaCl}$ solution, and $\mathrm{NaOH}$ solution, respectively, from DCM. Prolamin was not studied because only trace amounts exist in CM.

As shown in figure 1, DCM samples were mixed with distilled water at a solid/liquid ratio of 1:30 (w/v), stirred for $2 \mathrm{~h}$, and then centrifuged, and the residues were collected for further camelina protein fraction isolation. The supernatant was slowly adjusted to $\mathrm{pH} 3.0$ with $2 \mathrm{~N} \mathrm{HCl}$ and then centrifuged to precipitate the albumin fractions. The residues mentioned above were resuspended in water at a solid/liquid ratio of $1: 30(\mathrm{w} / \mathrm{v})$, adjusted to $\mathrm{pH} 12$ using $2 \mathrm{~N}$ $\mathrm{NaOH}$ with continuous stirring for $2 \mathrm{~h}$, and centrifuged. The supernatants were adjusted to $\mathrm{pH} 4.5$ and centrifuged to precipitate the protein fractions referred to as glutelin 1 . After centrifugation, the resulting residues were collected for further fraction extraction. The residues were resuspended in $5 \% \mathrm{NaCl}$ at a solid/liquid ratio of $1: 30(\mathrm{w} / \mathrm{v})$, adjusted to $\mathrm{pH} 8.0$ using $2 \mathrm{~N} \mathrm{NaOH}$, stirred for $2 \mathrm{~h}$, and then centrifuged. The supernatants were adjusted to $\mathrm{pH} 3.0$ with $2 \mathrm{~N} \mathrm{HCl}$ and centrifuged to isolate the protein fractions referred to as globulin 1. All camelina protein fractions except albumins were washed with distilled water for 


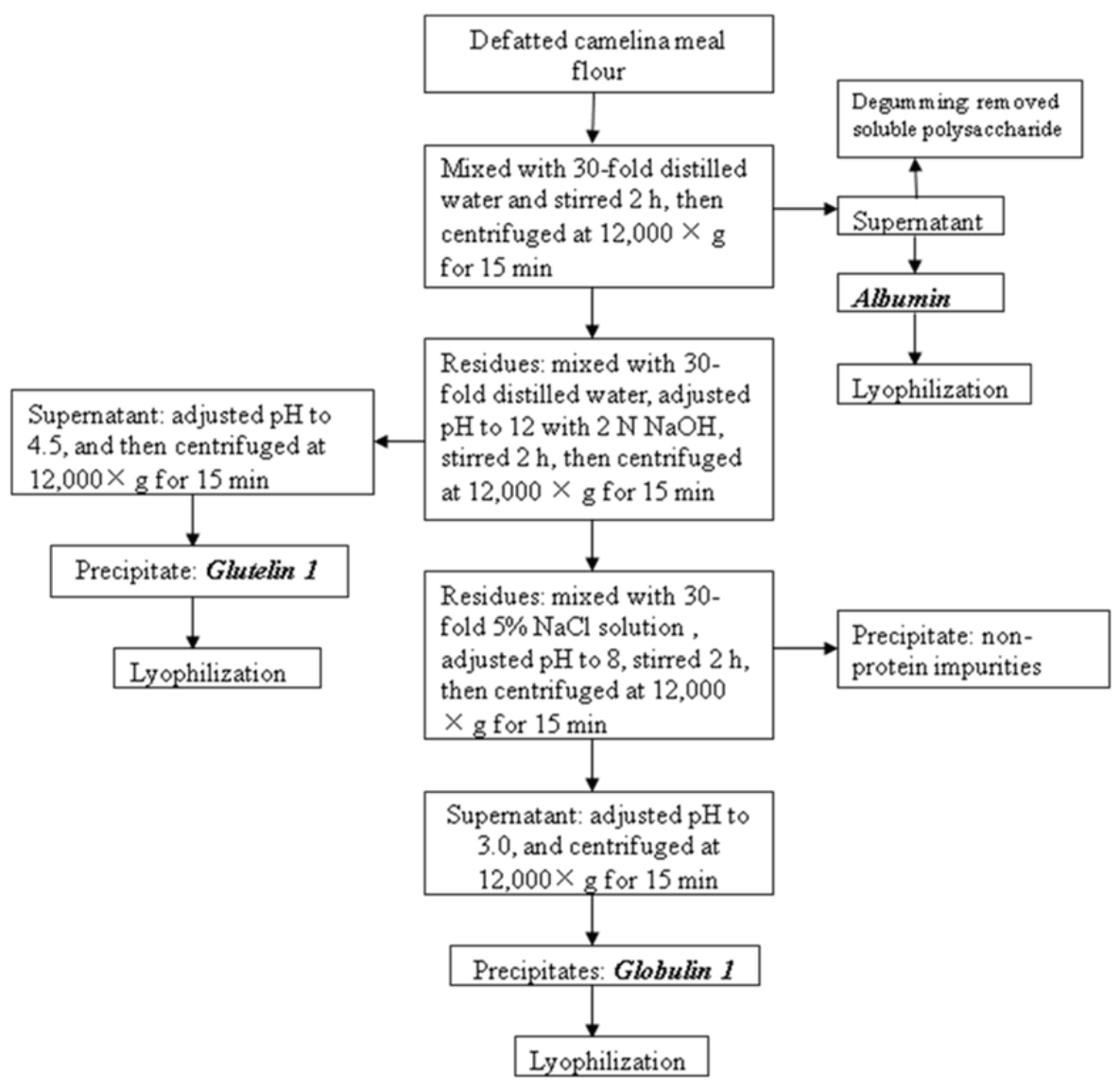

Figure 1. Flowchart of camelina protein fractions extraction procedure (S1).

three cycles, lyophilized, and ground into powder for further analyses.

Method 2 (S2): The main difference between S2 and S1 was that the globulin fractions were isolated after albumin but before glutelin. The protein fractions isolated with this method are referred to as globulin 2 and glutelin 2, respectively.

\section{Chemical Analysis}

Moisture content was measured with a V30 Compact Volumetric KF Titrator (Columbus, Ohio). Carbon (C), hydrogen $(\mathrm{H})$, nitrogen $(\mathrm{N})$, and sulfur $(\mathrm{S})$ contents were measured with a PerkinElmer 2400 Series II CHNS/O Elemental Analyzer (Shelton, Conn.). Nitrogen was converted to protein using a factor of 6.25 . All tests were performed in duplicate.

\section{Amino ACid Composition AnAlysis}

Amino acids profiles in camelina proteins were measured using the method described by Li et al. (2011a). Approximately $100 \mathrm{mg}$ of each sample was weighed and placed in $0.5 \mathrm{~mL}$ of $6 \mathrm{~N} \mathrm{HCl}$ along with the internal standard and hydrolyzed at $110^{\circ} \mathrm{C}$ for $20 \mathrm{~h}$. An aliquot, typically 10 or $20 \mu \mathrm{L}$, was diluted to $250 \mu \mathrm{L}$ with $0.4 \mathrm{M}$ borate buffer to raise the $\mathrm{pH}$. After precolumn derivatization with ophthalaldehyde (OPA) and 9-fluorenylmethyl chloroformate (FMOC), $1 \mu \mathrm{L}$ of this diluent was injected into an HPLC system with a C18 column (Hypersil AA-ODS, 2.1 $\times 200 \mathrm{~mm}, 5 \mu \mathrm{m}$ ). Mobile phase A was $20 \mathrm{mM}$ sodium acetate buffer containing $0.018 \% \quad(\mathrm{v} / \mathrm{v})$ triethylamine, $0.05 \mathrm{mM}$ EDTA, and $0.3 \%$ tetrahydrofuran with $\mathrm{pH}$ adjusted to 7.2 using acetic acid. Mobile phase B was a mixture of $100 \mathrm{mM}$ sodium acetate, acetonitrile, and methanol $(20: 40: 40, v / v)$. Elution conditions progressed from $100 \%$ A to $60 \% \mathrm{~B}$ in $17 \mathrm{~min}$ with a flow rate of $0.45 \mathrm{~mL} \mathrm{~min}$. Amino acid derivatives were detected with a fluorescent detector at 340/450 $\mathrm{nm}$ (excitation/emission) for primary amino acids and 266/305 nm for secondary amino acids. Human serum albumin was used as a control, and norvaline and sarcosine were used as internal standards.

\section{FOURIER TRANSFORM INFRARED SPECTROSCOPY}

Fourier transform infrared (FTIR) data of $0.5 \mathrm{~g}$ of dried protein powders were collected in the region of 400 to $4000 \mathrm{~cm}^{-1}$ with a PerkinElmer Spectrum 400 FT-IR/FTNIR spectrophotometer (Shelton, Conn.). Transmission spectra of 32 scans of each sample were collected at a resolution of $1 \mathrm{~cm}^{-1}$ in the reflectance mode. All samples were tested with duplications. Information on fat, carbohydrates, and protein in samples was given by absorptions. Because the objective of using FTIR was also to determine the relative amounts of $\alpha$-helix and $\beta$-sheet secondary structure protein, a band shape of each peak resolved by deconvolution needed to be produced that would allow peak area determination as a method of quantitative analysis. Fourier self-peak deconvolution (FSD), the most widely used tool, was used to identify the $\alpha$-helix and $\beta$-sheet in the protein amide I region, and modeling by the Peak Fitting Wizard 
tool with Gaussian function in Origin 8.0 data analysis and graphing software was also used (OriginLab Corp., Northampton, Mass.) to obtain areas of individual protein forms. The $\alpha$-helix and $\beta$-sheet content ratio was described as the ratio of peak areas (Wetzel et al., 2003; Yu et al., 2005).

\section{Transmission EleCtron Microscopy}

Transmission electron microscopy (TEM) was obtained using a model CM 100 TEM (FEI Co., Hillsboro, Ore.) operated at $100 \mathrm{kV}$. Camelina protein isolates were first dissolved in distilled water with a solids concentration of $0.05 \%(\mathrm{w} / \mathrm{w})$. Prepared protein samples were absorbed for approximately $30 \mathrm{~s}$ at room temperature onto Formvar/ carbon-coated 200-mesh copper grids (Electron Microscopy Sciences, Fort Washington, Pa.) and stained with $2 \%$ (w/v) uranyl acetate (Ladd Research Industries, Inc., Burlington, Vt.) for $60 \mathrm{~s}$ at room temperature before being viewed by TEM.

\section{Thermal Gravimetric AnAlysis}

Thermal gravimetric analysis (TGA) of camelina proteins was conducted with a Perkin-Elmer TGA 7 (Norwalk, Conn.) in a nitrogen atmosphere. Approximately $10 \mathrm{mg}$ of ground powder was weighed into a platinum cup and scanned from $25^{\circ} \mathrm{C}$ to $900^{\circ} \mathrm{C}$ at a heating rate of $10^{\circ} \mathrm{C} \mathrm{min}{ }^{-1}$. The maximum degradation rate was calculated as mass (\%) at peak temperature divided by peak temperature.

\section{SIZE-EXCLUSION CHROMATOGRAPHY}

Size-exclusion chromatography (SEC) analysis was conducted as described by Bean et al. (2006). A highperformance liquid chromatography (HPLC) system (1100, Agilent, Palo Alto, Cal.) with a $300 \mathrm{~mm} \times 7.8 \mathrm{~mm}$ BioSep4000 column and security guard columns (Phenomonex, Torrance, Cal.) was used. The mobile phase was a $\mathrm{pH} 7$ sodium phosphate buffer $(50 \mathrm{mM})$ with $1 \%$ SDS added. Column temperature was maintained at $25^{\circ} \mathrm{C}$, and flow rate

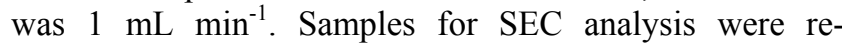
dissolved in a $\mathrm{pH} 7$ sodium borate buffer $(12.5 \mathrm{mM})$ plus $1 \%$ SDS with or without $2 \% \beta$-ME at a constant final protein concentration of $5 \mathrm{mg} \mathrm{L}^{-1}$. Standard proteins, BSA $(66 \mathrm{kDa})$, carbonic anhydrase $(29 \mathrm{kDa})$, and glutathione (307.3 Da), were analyzed to estimate the molecular weight distribution of camelina protein fractions separated by SEC.

\section{Statistical Analysis}

Data from experiments carried out at least in duplicate were analyzed through analysis of variance (ANOVA) and least significant difference (LSD) at the 0.05 level according to procedures in the SAS statistical software package (SAS Institute, Inc., Cary, N.C.).

\section{RESUlTS AND DiscusSiON \\ Camelina Protein Solubilities AND Precipitation Properties}

According to the Bradford standard curve, net absorbance at $595 \mathrm{~nm}$ showed a linear relationship with bovine serum albumin (BSA) at concentrations from 0.0 to $1.0 \mathrm{mg}$
$\mathrm{mL}^{-1}$. The linear relationship is expressed by equation 1 with $\mathrm{R}^{2}$ of 0.999 :

$$
Y=0.88901 X+0.0226
$$

where $Y$ is absorbance at $595 \mathrm{~nm}$, and $X$ is protein concentration $\left(\mathrm{mg} \mathrm{mL}^{-1}\right)$. As shown in figure 2 , solubility of glutelin was highly sensitive to $\mathrm{pH}$ values. Solubility of glutelin increased slightly from $\mathrm{pH} 10.0$ to $\mathrm{pH} 11.0$ and then reached its peak value around $\mathrm{pH}$ 12.0. Therefore, $\mathrm{pH} 12$ was used for the solubilization of camelina glutelin in this study.

The purpose of characterizing precipitation properties of camelina proteins was to identify the $\mathrm{pH}$ value at which the solubility is minimum (MS-pH). As shown in figure 3, the albumin and glutelin fractions exhibited a typical U-shaped solubility profile, whereas the globulin fraction showed a step shape. The lowest protein solubility was observed in the $\mathrm{pH}$ range from 2.5 to 3.0 for the albumin fraction and $\mathrm{pH} 4.0$ to 5.0 for the glutelin fraction. For the globulin fraction, protein concentration decreased significantly from $\mathrm{pH}$ 6.93 to $\mathrm{pH} 4.0$ and then leveled off from $\mathrm{pH} 4.0$ to 12.0. In this case, the MS-pH values of camelina protein fractions were considered to be $\mathrm{pH} 3.0,4.0$ to 5.0 , and 3.0 for albu$\mathrm{min}$, glutelin, and globulin, respectively.

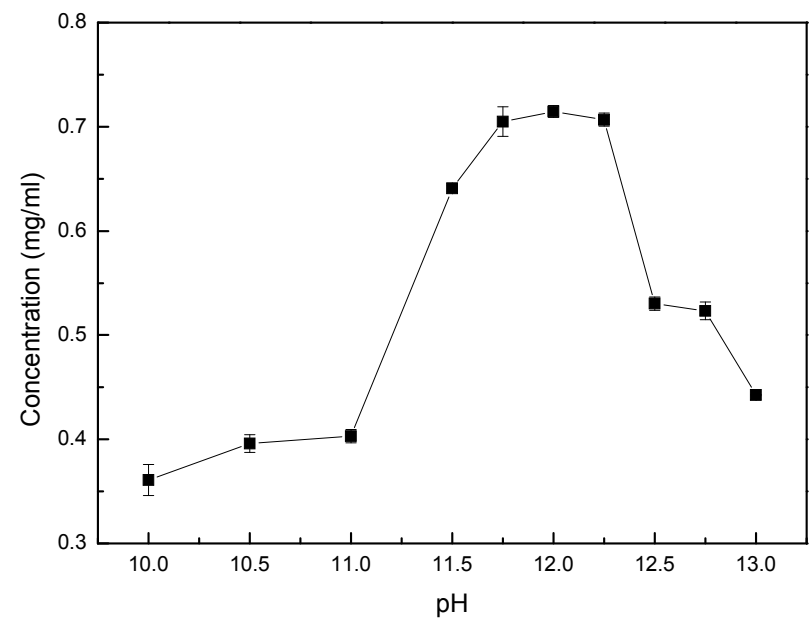

Figure 2. Effect of pH on solubility of glutelin.

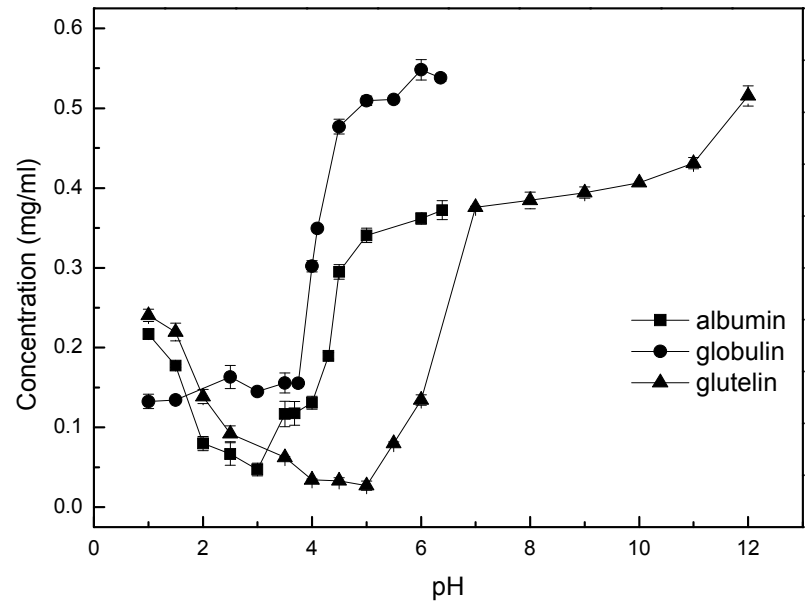

Figure 3. Effect of $\mathrm{pH}$ on precipitation properties of protein fractions. 


\section{Partial Proximate Analysis and Elemental Composition of CAMELINA Proteins}

Table 1 shows the partial proximate and elemental compositions of camelina fractions. The DCM consisted of approximately $38.12 \%$ crude protein. For all three isolation methods, glutelin ( $48.32 \%$ to $64.64 \%)$ was the major fraction in protein, followed by globulins $(13.03 \%$ to $17.67 \%)$ and albumins (10.54\%).

More protein isolates were recovered with S0 (48.67\%) than with S1 (41.54\%) and S2 (36.86\%); however, the protein purity with S0 $(57.56 \%$ to $70.81 \%)$ was far lower than that of S1 $(81.0 \%$ to $87.04 \%)$ and S2 $(83.68 \%$ to $86.93 \%)$, which could be attributed to the presence of gum in S0. Similarly, the albumin fraction showed lower protein purity $(56.57 \%)$ than the globulin and glutelin fractions $(81.0 \%$ to $87.0 \%$ ) due to gum, which was extracted along with the albumin protein and consequently led to low protein purity. In addition, much purer globulin 2 and glutelin 1 fractions were extracted than globulin 0 and glutelin 0 , indicating that the presence of gum negatively affected the protein isolates' purity. The DCM-water slurry was very thick and sticky when those gums were present, possibly causing inefficient solubilization of protein in the slurry and resulting in lower protein extraction yield.

More glutelin was extracted in S1 than in S2, which could be attributed to the effect of $\mathrm{NaCl}$. As described in similar studies, $\mathrm{NaCl}$ can negatively affect protein solubility in specific pH ranges. Carbonaro et al. (1997) found that lower solubility of fava bean, lentil, and chickpea proteins (all proteins had a MS-pH around $\mathrm{pH} 4.0$ ) in $\mathrm{NaCl}$ at $\mathrm{pH}$ above 7.5 or with $\mathrm{pH}$ from 1.0 to 3.0 could be ascribed to increased hydrophobic interaction. Hydrophobic interactions are the driving force for protein-protein aggregation, leading to protein insolubilization. Makkar et al. (2008) also reported that recovery of Jatropha protein decreased with the presence of $\mathrm{NaCl}$ at $\mathrm{pH} 10$ or 11 due to an increase in ionic strength and the resulting increase in hydrophobic interaction, or perhaps due to the "salting out" effect of $\mathrm{NaCl}$ on protein resulting from competition between charged proteins and salt ions for necessary water for solvation (Badifu and Akubor, 2001). In contrast, Carbonaro et al. (1997) indicated that the shielding of charged groups of dry bean by $\mathrm{NaCl}$ resulted in increased electrostatic repulsive force that reduced protein aggregation and therefore improved solubility. In this research, camelina

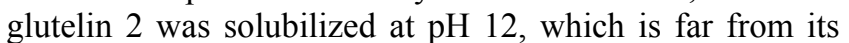
MS-pH (pH 4.0 to 5.0) with the presence of $\mathrm{NaCl}$, resulting in a lower recovery rate for glutelin 2 due to strong ionic strength and protein aggregations driven from increased hydrophobic forces, as described by Makkar et al. (2008).

Some protein remained in the residues: $3.45 \%$ for $\mathrm{S} 1$ and $5.86 \%$ for S2. Furthermore, the sum of isolated pure proteins $(\%)$ and unextracted proteins in residues (\%) was not $100 \%$; instead, the sum was $97.24 \%$ for S1 and $91.89 \%$ for S2, implying that part of the proteins was lost during the extraction process.

The elemental composition of camelina proteins varied for different protein fractions (table 1). The glutelin and albumin fractions contained higher levels of C $(42.33 \%$ to $49.22 \%), \mathrm{H}(6.30 \%$ to $7.21 \%)$, and $\mathrm{S}(2.03 \%$ to $2.34 \%)$ than globulins $(31.08 \%$ to $39.51 \%, 4.55 \%$ to $5.78 \%$, and $1.62 \%$ to $1.75 \%$, respectively). The sulfur in protein is known from the side-chains of amino acids methionine and cysteine (Brosnan and Brosnan, 2006). Higher levels of sulfur in albumin and glutelins coincide with higher content of methionine or cysteine in the amino acid profiles of camelina proteins, as shown in table 2 .

\section{AMino ACID Composition}

Sixteen kinds of amino acids were detected and quantified in camelina proteins (table 2). Tryptophan and cysteine in camelina accounted for only $1.15 \%$ and $2.12 \%$ of the total amino acids, respectively (Zubr, 2002). However, tryptophan and cysteine were not detected because they were destroyed by the liquid $\mathrm{HCl}$ hydrolysis assay during the test, which may be one reason why the total sum of amino acids was lower than the protein content obtained by the nitrogen combustion method (table 1). Another reason may be the presence of non-protein nitrogen (NPN) in camelina. Although no published data are available on NPN content in camelina, NPN is very common in oilseeds. NPN content in soy, rape, and sunflower is up to $12.3 \%, 29.0 \%$, and $15.4 \%$, respectively, using $1 \%$ trichloroacetic acid as the extracting buffer (Bhatty and Finlayson, 1973).

Table 1. Partial proximate and elemental compositions of camelina meal and protein fractions produced by different isolation sequences. ${ }^{\text {[a] }}$

\begin{tabular}{|c|c|c|c|c|c|c|c|c|c|}
\hline \multirow{2}{*}{$\begin{array}{c}\text { Camelina } \\
\text { Protein } \\
\text { Samples }\end{array}$} & \multirow{2}{*}{$\begin{array}{c}\text { Moisture } \\
\text { Content } \\
(\% \text { d.b. })\end{array}$} & \multirow[t]{2}{*}{$\begin{array}{l}\text { Weight of } \\
\text { Isolates } \\
\text { Compared } \\
\text { to DCM } \\
\text { (\% d.b.) }\end{array}$} & \multirow{2}{*}{$\begin{array}{l}\text { Protein } \\
\text { Content } \\
\text { (\% d.b.) }\end{array}$} & \multirow[t]{2}{*}{$\begin{array}{l}\text { Weight } \\
\text { of Protein } \\
\text { Compared } \\
\text { to DCM } \\
\text { (\% d.b.) }\end{array}$} & \multirow[t]{2}{*}{$\begin{array}{l}\text { Weight of Protein } \\
\text { Compared to } \\
\text { Total Protein } \\
\text { in DCM } \\
\text { (\% d.b.) }\end{array}$} & \multicolumn{4}{|c|}{$\begin{array}{c}\text { Elemental Composition of Protein Sources } \\
(\% \text { d.b. })\end{array}$} \\
\hline & & & & & & $\mathrm{C}$ & $\mathrm{H}$ & $\mathrm{N}$ & $\mathrm{S}$ \\
\hline DCM & $9.35 \mathrm{a}$ & - & 38.12 & - & - & $45.31 \mathrm{~b}$ & $6.92 \mathrm{a}$ & $6.10 \mathrm{af}$ & $2.12 \mathrm{c}$ \\
\hline Albumin & $7.30 \mathrm{e}$ & $7.10 \mathrm{~h}$ & 56.57 & 4.02 & 10.54 & $42.33 \mathrm{c}$ & $6.30 \mathrm{~b}$ & $9.05 \mathrm{e}$ & $2.27 \mathrm{ab}$ \\
\hline Globulin 0 & $7.20 \mathrm{e}$ & $10.66 \mathrm{~g}$ & 57.56 & 6.14 & 16.10 & $31.08 \mathrm{e}$ & $4.55 \mathrm{e}$ & $9.21 \mathrm{e}$ & $1.75 \mathrm{~d}$ \\
\hline Glutelin 0 & $8.73 \mathrm{c}$ & $30.91 \mathrm{~d}$ & 70.81 & 21.89 & 57.42 & $45.92 \mathrm{~b}$ & $6.71 \mathrm{ab}$ & $11.33 \mathrm{~d}$ & $2.22 \mathrm{~b}$ \\
\hline Globulin 1 & $6.57 \mathrm{f}$ & $6.13 \mathrm{i}$ & 81.00 & 4.97 & 13.03 & $37.96 \mathrm{~d}$ & $5.54 \mathrm{~cd}$ & $12.96 \mathrm{c}$ & $1.62 \mathrm{e}$ \\
\hline Glutelin 1 & $6.87 \mathrm{~g}$ & $28.31 \mathrm{e}$ & 87.04 & 24.64 & 64.64 & $49.22 \mathrm{a}$ & $7.12 \mathrm{a}$ & $13.93 \mathrm{a}$ & $2.34 \mathrm{a}$ \\
\hline Globulin 2 & $6.14 \mathrm{~h}$ & $7.75 \mathrm{~h}$ & 86.93 & 6.74 & 17.67 & $39.51 \mathrm{~d}$ & $5.78 \mathrm{c}$ & $13.91 \mathrm{a}$ & $1.70 \mathrm{de}$ \\
\hline Glutelin 2 & $7.54 \mathrm{~d}$ & $22.01 \mathrm{f}$ & 83.68 & 18.42 & 48.32 & $46.03 \mathrm{~b}$ & $6.71 \mathrm{ab}$ & $13.39 \mathrm{~b}$ & $2.03 \mathrm{c}$ \\
\hline Residue 1 & $9.03 \mathrm{~b}$ & $40.30 \mathrm{~b}$ & 8.55 & 3.45 & 9.04 & $27.76 \mathrm{f}$ & $3.91 \mathrm{f}$ & $1.37 \mathrm{~h}$ & $0.94 \mathrm{~g}$ \\
\hline Residue 2 & $9.03 \mathrm{~b}$ & $48.11 \mathrm{a}$ & 12.18 & 5.86 & 15.37 & $39.15 \mathrm{~d}$ & $5.35 \mathrm{~d}$ & $1.95 \mathrm{~g}$ & $1.26 \mathrm{f}$ \\
\hline Sum of S0 & & $48.67 \mathrm{a}$ & & 32.04 & 84.05 & & & & \\
\hline Sum of S1 & & $41.54 \mathrm{~b}$ & & 33.62 & 88.20 & & & & \\
\hline Sum of S2 & & $36.86 \mathrm{c}$ & & 29.17 & 76.52 & & & & \\
\hline
\end{tabular}


Table 2. Amino acid composition (\% of total) of DCM, canola meal, and camelina protein fractions.

\begin{tabular}{|c|c|c|c|c|c|c|c|c|c|}
\hline Amino Acid ${ }^{[\mathrm{a}]}$ & Albumin & $\begin{array}{c}\text { Globulin } \\
0 \\
\end{array}$ & $\begin{array}{c}\text { Glutelin } \\
0\end{array}$ & $\begin{array}{c}\text { Globulin } \\
1 \\
\end{array}$ & $\begin{array}{c}\text { Glutelin } \\
1 \\
\end{array}$ & $\begin{array}{c}\text { Globulin } \\
2 \\
\end{array}$ & $\begin{array}{c}\text { Glutelin } \\
2\end{array}$ & $\mathrm{DCM}^{[\mathrm{b}]}$ & $\begin{array}{l}\text { Canola } \\
\text { Meal }^{[\mathrm{c}]}\end{array}$ \\
\hline \multicolumn{10}{|l|}{ Essential } \\
\hline Histidine & 2.84 & 2.97 & 3.02 & 3.04 & 3.04 & 3.00 & 3.02 & 2.90 & 3.32 \\
\hline Isoleucine* & 4.70 & 4.99 & 4.85 & 4.96 & 5.01 & 4.93 & 5.16 & 4.94 & 5.80 \\
\hline Leucine* & 8.14 & 9.21 & 8.66 & 9.14 & 8.93 & 9.37 & 9.12 & 8.32 & 8.86 \\
\hline Lysine & 5.88 & 4.42 & 5.41 & 4.36 & 5.05 & 4.12 & 5.93 & 5.93 & 5.85 \\
\hline Methionine* & 1.85 & 1.83 & 2.14 & 1.68 & 2.27 & 1.73 & 2.46 & 1.70 & 1.74 \\
\hline Phenylalanine* & 5.77 & 6.50 & 5.60 & 6.64 & 5.63 & 6.84 & 5.41 & 5.08 & 5.00 \\
\hline Threonine & 5.35 & 4.74 & 5.14 & 4.78 & 5.05 & 4.73 & 5.81 & 5.26 & 5.45 \\
\hline Valine & 5.75 & 6.09 & 5.71 & 6.09 & 5.77 & 6.11 & 5.84 & 5.63 & 6.05 \\
\hline Total essential & 40.29 & 40.75 & 40.54 & 40.69 & 40.75 & 40.85 & 42.74 & 39.75 & 42.07 \\
\hline \multicolumn{10}{|l|}{ Non-essential } \\
\hline Alanine* & 5.87 & 5.36 & 5.78 & 5.29 & 5.62 & 5.22 & 6.26 & 5.68 & 5.40 \\
\hline Aspartate & 11.45 & 11.56 & 9.97 & 11.19 & 9.70 & 11.83 & 9.68 & 9.84 & 8.44 \\
\hline Glutamate & 18.46 & 19.23 & 19.11 & 19.03 & 19.24 & 18.92 & 15.65 & 19.94 & 22.37 \\
\hline Serine & 6.41 & 5.98 & 6.12 & 5.91 & 6.02 & 5.92 & 6.44 & 6.09 & 5.47 \\
\hline Arginine & 7.71 & 7.60 & 8.42 & 8.16 & 8.53 & 7.77 & 8.09 & 8.57 & 6.95 \\
\hline Glycine & 6.24 & 5.88 & 6.13 & 5.95 & 6.12 & 5.79 & 6.46 & 6.40 & 6.07 \\
\hline Tyrosine & 3.58 & 3.63 & 3.93 & 3.79 & 4.02 & 3.71 & 4.69 & 3.73 & 3.23 \\
\hline Ornithine & 0 & 0 & 0 & 0 & 0 & 0 & 0 & 0 & 0 \\
\hline Total non-essential & 59.71 & 59.24 & 59.46 & 59.31 & 59.25 & 59.15 & 57.26 & 60.25 & 57.93 \\
\hline Total amino acid & 100 & 100 & 100 & 100 & 100 & 100 & 100 & 100 & 100 \\
\hline Total protein & 46.35 & 51.05 & 61.84 & 67.38 & 68.91 & 76.10 & 72.07 & 34.13 & 34.84 \\
\hline
\end{tabular}

[a] Asterisks (*) indicate hydrophilic amino acids.

[b] $\mathrm{DCM}=$ defatted camelina meal.

[c] Source: Li et al. (2011a).

Camelina proteins are characterized by high content of glutamate $(18.46 \%$ to $19.23 \%)$, aspartate $(9.68 \%$ to $11.83 \%)$, leucine $(8.14 \%$ to $9.17 \%)$, arginine $(7.60 \%$ to $8.57 \%$ ), and phenylalanine $(5.08 \%$ to $6.84 \%$ ) but low content of ornithine $(0 \%)$, methionine $(1.68 \%$ to $2.46 \%)$, histidine $(2.84 \%$ to $3.04 \%)$, and tyrosine $(3.58 \%$ to $4.02 \%)$. Globulins showed lower levels of lysine, methionine, threonine, alanine, and glycine and higher levels of leucine, phenylalanine, valine, and aspartate. Notably, methionine, a sulfur-containing amino acid, was higher in glutelins than in globulins, which is attributed to a high sulfur content in glutelins. Compared with globulins, albumin had lower levels of isoleucine, leucine, phenylalanine, valine, and lysine, but albumin exceeded globulins for the content of lysine, threonine, alanine, serine, and glycine. Furthermore, albumin exhibited lower levels of histidine, leucine, methionine, glutamate, and arginine and higher level of lysine, threonine, and aspartate than glutelins.

Amino acids were classified into groups according to their physical, chemical, and structural properties. Nutritionally, camelina proteins contained approximately $40 \%$ essential amino acids that cannot be synthesized by human and many farm animals, and approximately $60 \%$ nonessential amino acids that can be produced in humans and animals. The percentage of essential amino acids in camelina is slightly lower than in canola protein $(42 \%)$ ( $\mathrm{Li}$ et al., 2011a), sorghum protein (48\%) (Li et al., 2011b), and soy protein (49\%) (Khorasani et al., 1990). The lysine content $(4.12 \%$ to $5.88 \%)$ in all camelina protein fractions and the phenylalanine content (5.08\% to $6.50 \%)$ in DCM, albumin, and glutelins were lower than World Health Organization (WHO) standards for children at 0.5 years old $(6.4 \%$ for lysine, $5.9 \%$ for phenylalanine), but all essential amino acid contents in camelina protein meet or exceed WHO amino acid requirement standards for children over one year old and adults (WHO, 2007).
Based on hydrophobicity, amino acids can be grouped into hydrophobic (non-polar) and hydrophilic (polar) types. Hydrophobic amino acids have side-chains that do not prefer an aqueous environment. Betts and Russell (2003) reported that these amino acids are generally buried within the hydrophobic core of the protein or within the lipid portion of the membrane. Among the detected amino acids, alanine, methionine, phenylananine, isoleucine, and leucine belong to the hydrophobic group and account for approximately $26.34 \%$ to $28.40 \%$ of camelina protein fractions (table 2). Albumin showed the lowest hydrophobic property, whereas globulin 2 was the most hydrophobic. Hydrophobic properties of camelina proteins are comparable to canola protein $(26 \%)$ but lower than soy protein $(37 \%)$ and sorghum protein (57\%) (Li et al., 2011a).

\section{SIZE-EXCLUSION CHROMATOGRAPHY}

Molecular weight (MW) distributions of camelina protein fractions were characterized with SEC in the presence and absence of reducing agents (fig. 4a). Under nonreducing conditions for all protein samples, three major peaks were detected at $8 \mathrm{~min}, 8.75 \mathrm{~min}$, and $9.5 \mathrm{~min}$, respectively. The major peak was around $66 \mathrm{kDa}$, except in the glutelin 2 fraction, which exhibited a major peak at approximately $9.5 \mathrm{~min}$ with MW less than $29 \mathrm{kDa}$. Globulin 0 and globulin 2 showed stronger peak intensity than globulin 1 at MW around $66 \mathrm{kDa}$, indicating more protein subunits with larger MW present in globulin 0 and 1 . This difference in MW among globulins may be ascribed to effects of the initial protein isolating conditions and sequences. As stated in the protein isolation steps, globulin 0 and globulin 2 were extracted with $5 \% \mathrm{NaCl}$ solution, whereas globulin 1 was extracted from the pellets already treated with $\mathrm{NaOH}$ solution. Some $\mathrm{NaOH}$ residue could have remained when performing globulin 1 isolation, so the globulin 1 fraction was extracted as a result of the combined action of both 
$\mathrm{NaCl}$ and $\mathrm{NaOH}$. In addition, the albumin and glutelin fractions both had a small peak around 5 min, indicating the presence of the high MW protein subunits. However, this peak was barely detected in the globulin fraction except globulin 1, which also could be attributed to the combined action of $\mathrm{NaCl}$ and $\mathrm{NaOH}$ in the globulin 1 fraction.

In the presence of a reducing agent (fig. $4 \mathrm{~b}$ ), the intensity of the peak around $66 \mathrm{kDa}$ decreased significantly and shifted to MW lower than $29 \mathrm{kDa}$, indicating that disulfidebonded cross-linked subunits were present in all protein fractions. Many studies have reported that glutelins from corn and wheat are composed of a high level of subunits linked by disulfide bonds (Nielsen et al., 1970; Masci et al., 1998). The high intensity of the peak at $66 \mathrm{kDa}$ in the globulin 0 and 2 fractions prove that they contained more disulfide linkages; however, according to tables 1 and 2, more sulfur content and methionine were detected in the glutelin fraction, which should have translated into a larger number of disulfide bonds than in the globulin fraction. The reason for this may be due to the fact that $\mathrm{NaOH}$ could have destroyed cystine and cleft disulfide bonds during extraction

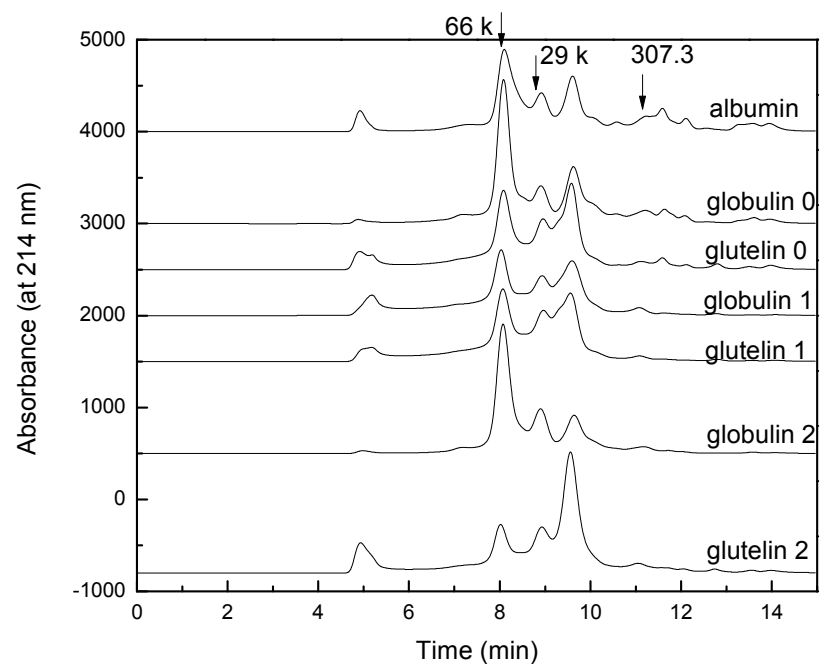

(a)

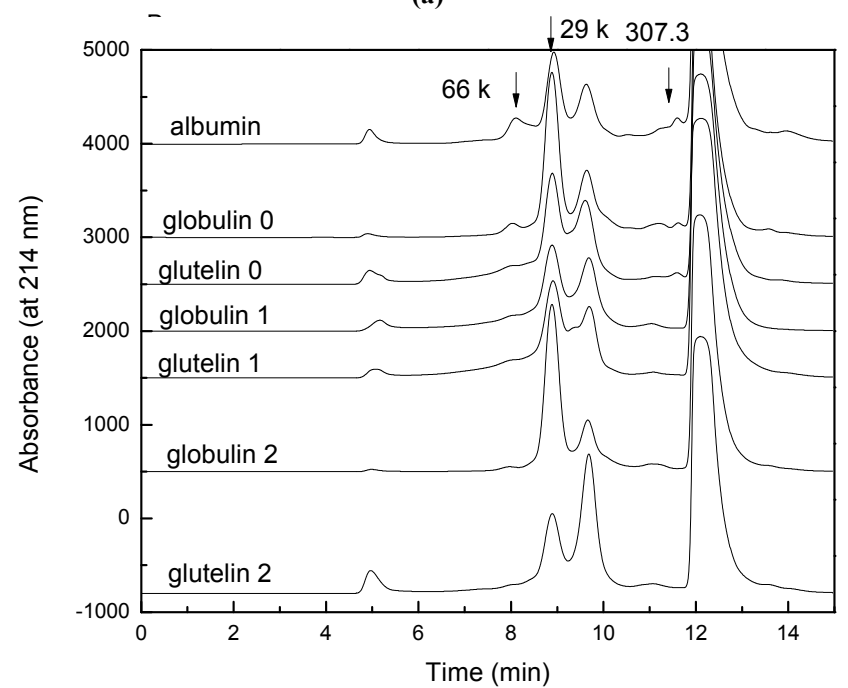

(b)

Figure 4. SEC separations of camelina proteins at (a) non-reducing and (b) reducing conditions.
(Nielsen et al., 1970; Tecson et al., 1971), thus leading to reduced disulfide bonds in the glutelin fraction. Furthermore, large MW peaks around 5 min were still detected under the reducing condition, indicating that protein aggregates were stabilized by covalent bonds other than disulfide bonds in those protein fractions.

\section{FOURIER TRANSFORM INFRARED SPECTROSCOPY}

As shown in figure $5 \mathrm{a}$, typical oil absorption bands localized at 1710 and $1745 \mathrm{~cm}^{-1}(\mathrm{C}=\mathrm{O}$ stretching) and at 2853, 2924, and $3006 \mathrm{~cm}^{-1}$ (C-H stretching) were detected in the spectra of DCM (Guillén and Cabo, 1997). The significant diminishment or disappearance of these bands indicated only trace to low oil content in the isolated protein fractions. $\mathrm{Ab}-$ sorptions in the range of 900 to $1250 \mathrm{~cm}^{-1}$ related to C-O stretching vibrations in polysaccharides were detected for all samples with different intensities. Consistent with previous results, albumin and proteins extracted with S0 with low protein purities (table 1) had higher peak intensity at 1050 $\mathrm{cm}^{-1}$, indicating absorption of polysaccharides, than other fractions. It was reported that camelina seeds contained polysaccharides, which showed good water-binding capacity and were capable of aiding seed germination in dry environments (Grady and Nleya, 2010).

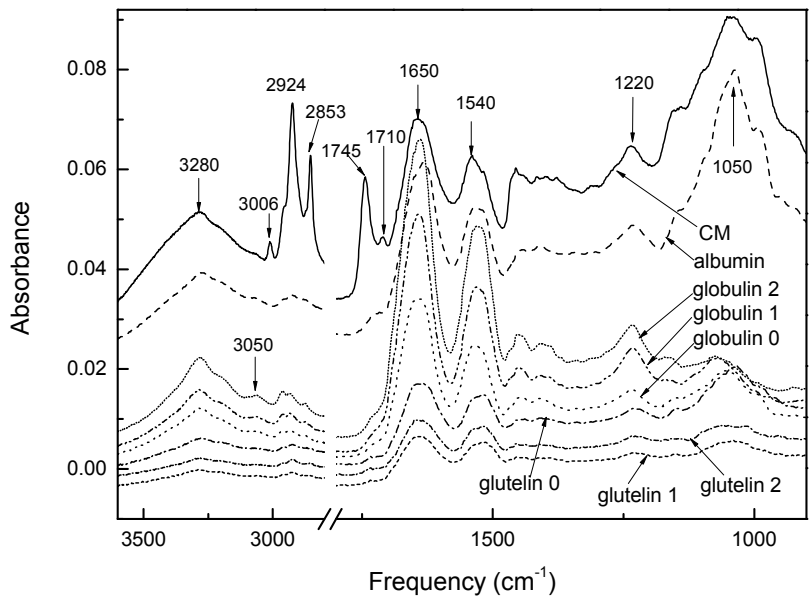

(a)

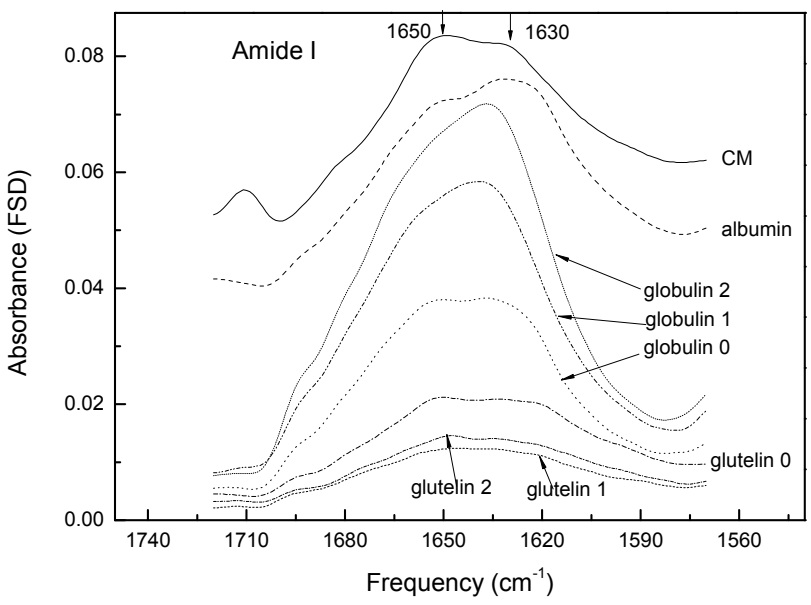

(b)

Figure 5. (a) FTIR analysis of camelina meal and proteins and (b) $\alpha$-helix, $\beta$-sheet identification in amide $I$. 
Table 3. Fourier self-peak deconvolution of amide I.

\begin{tabular}{|c|c|c|c|c|c|}
\hline \multirow{2}{*}{$\begin{array}{l}\text { Camelina } \\
\text { Protein } \\
\text { Samples }\end{array}$} & \multicolumn{2}{|c|}{$\alpha$-Helix } & \multicolumn{2}{|c|}{$\beta$-Sheet } & \multirow{2}{*}{$\begin{array}{c}\text { Area Ratio of } \\
\alpha \text {-Helix to } \\
\beta \text {-Sheet }\end{array}$} \\
\hline & $\begin{array}{c}\text { Frequency } \\
\left(\mathrm{cm}^{-1}\right)\end{array}$ & Area & $\begin{array}{c}\text { Frequency } \\
\left(\mathrm{cm}^{-1}\right)\end{array}$ & Area & \\
\hline $\mathrm{CM}^{[\mathrm{a}]}$ & 1650 & 1.16 & 1630 & 1.04 & 1.12 \\
\hline Albumin & 1650 & 1.09 & 1630 & 1.29 & 0.84 \\
\hline Globulin 0 & 1650 & 1.12 & 1634 & 1.12 & 1.00 \\
\hline Glutelin 0 & 1650 & 0.66 & 1628 & 0.64 & 1.03 \\
\hline Globulin 1 & 1650 & 1.54 & 1637 & 1.70 & 0.91 \\
\hline Glutelin 1 & 1650 & 0.39 & 1626 & 0.39 & 1.00 \\
\hline Globulin 2 & 1650 & 1.98 & 1635 & 2.18 & 0.91 \\
\hline Glutelin 2 & 1650 & 0.42 & 1630 & 0.40 & 1.05 \\
\hline
\end{tabular}

[a] $\mathrm{CM}=$ camelina meal.

Protein units give rise to nine characteristic absorption bands, namely, amide $\mathrm{A}, \mathrm{B}$, and I to VII, among which the amide I and II bands are the most prominent vibrational bands of the protein backbone (Kong and $\mathrm{Yu}, 2007$ ). The amide I absorption contains contributions from primarily $\mathrm{C}=\mathrm{O}$ stretching vibrations $(80 \%)$ with a minor $\mathrm{C}-\mathrm{N}$ stretching vibration, whereas the amide II absorption appears to arise from N-H bending vibrations $(60 \%)$ coupled with C-N stretching vibrations (40\%) (Jackson and Mantsch, 1995). Peaks at 1630 and $1520 \mathrm{~cm}^{-1}$ are dominated by camelina protein secondary structures amide I and amide II, respectively (Yu et al., 2005). After deconvolution, the $\alpha$-helix in amide I was shown at $1650 \mathrm{~cm}^{-1}$ for all protein samples (fig. 5b). Absorptions of $\beta$-sheet were in the frequency range of 1626 to $1637 \mathrm{~cm}^{-1}$. Interestingly, absorption peaks of globulin fractions were at higher frequencies than those of glutelin and albumin fractions and DCM. The ratio of $\alpha-$ helix and $\beta$-sheet in amide I was quantified by the peak area (table 3). DCM showed higher a $\alpha$-helix to $\beta$-sheet ratio (1.12) than the other samples, and albumin had the lowest ratio (0.84). Glutelin exhibited a higher $\alpha$-helix to $\beta$ sheet ratio (1.03 to 1.05$)$ than globulin (0.91 to 1.00$)$, indicating a higher $\alpha$-helix portion in the glutelin fraction.
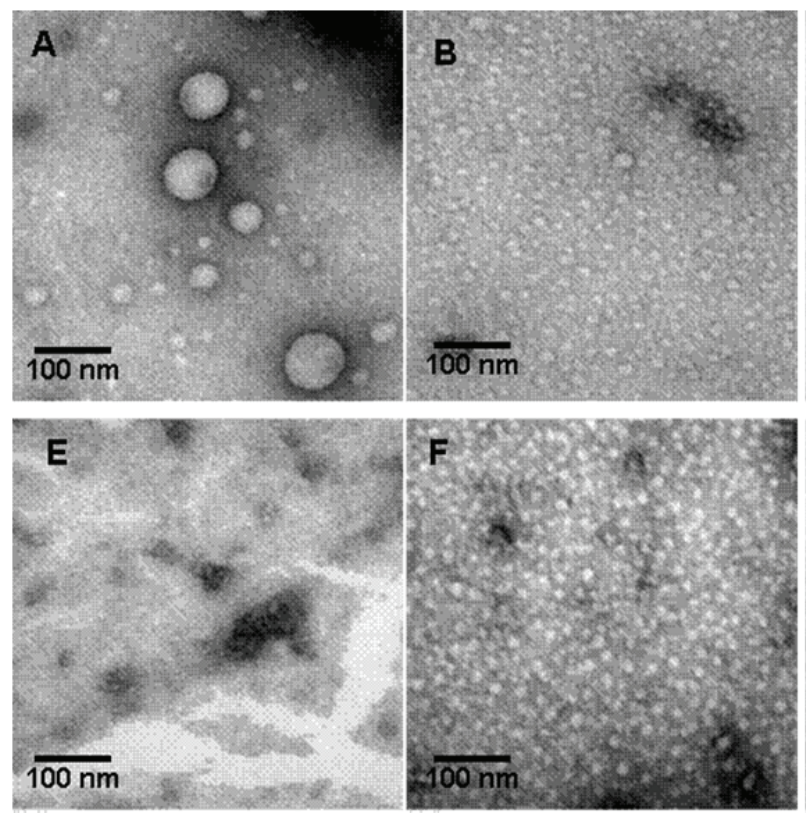

\section{Morphological Properties}

TEM images of camelina protein fractions are presented in figure 6 at 130,000× magnification. Albumin showed a spherical shape with diameters from 10 to $85 \mathrm{~nm}$ (image A in fig. 6), which is bigger than globulins (images B, D, and $\mathrm{F}$ in fig. 6) and glutelins (images $\mathrm{C}, \mathrm{E}$, and $\mathrm{G}$ in fig. 6) on average. All globulins isolated with various methods exhibited a spherical shape with similar diameters of around $10 \mathrm{~nm}$ (images B, D, and F in fig. 6) and distributed uniformly. For the glutelins (images C, E, and G in fig. 6), irregular and highly dense protein clusters were observed that comprised a mixture of spherical and rod-shaped clusters with diameters from less than $10 \mathrm{~nm}$ to several hundred nanometers. In short, larger protein aggregates were exhibited in albumin and glutelin fractions compared with globulin fractions.

Generally, aggregates of proteins may arise from several mechanisms and may be classified in numerous ways, including soluble/insoluble, covalent/non-covalent, reversible/irreversible, and native/denatured, thus influencing the amount of aggregate produced during the cell culture and purification process. As discussed earlier in the SizeExclusion Chromatography section, high MW subunits stabilized by covalent bonds were observed in all glutelin fractions, which may contribute to the larger size of protein aggregates. Cromwell et al. (2006) concluded that disulfide bonds played an important role in protein aggregates and the resulting compact protein structures, but the glutelin fractions contained fewer disulfide bond-linked subunits than the globulin fractions (fig. 4a), indicating that disulfide bonds were insignificant in these larger aggregate formations. Moreover, oxidation of tyrosine may also result in covalent aggregation through the formation of bityrosine (Cromwell et al., 2006). In the amino acid profiles of camelina protein (table 2), glutelins contained more tyrosine than globulins, leading to the possibility that more covalent bonds could be formed through
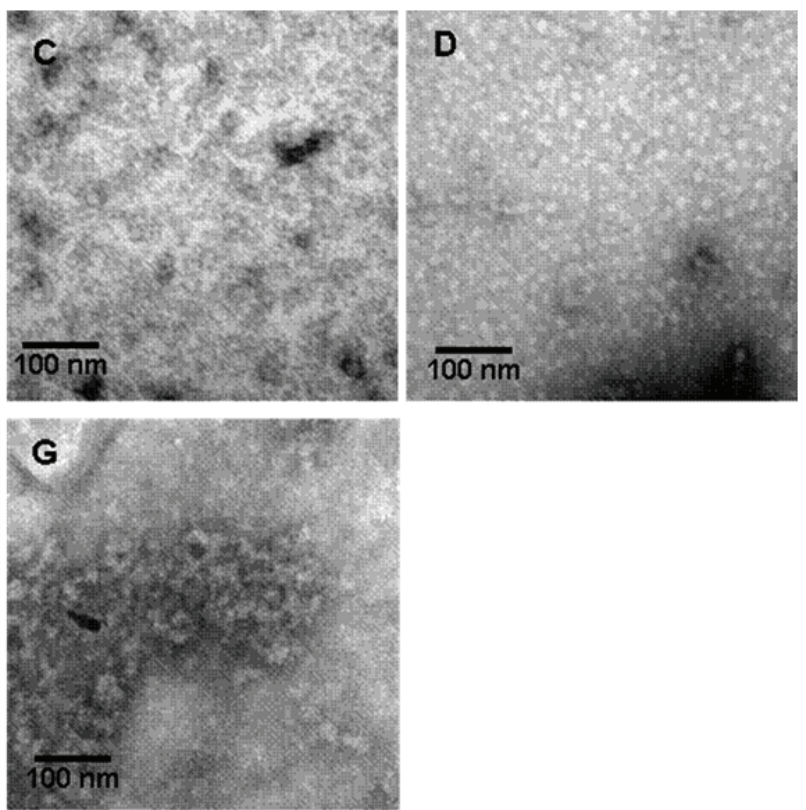

Figure 6. TEM images of DCM and camelina proteins: $\mathbf{A}=$ albumin, $\mathbf{B}=$ globulin $\mathbf{0}, \mathbf{C}=$ glutelin $\mathbf{0}, \mathbf{D}=$ globulin $1, \mathbf{E}=$ glutelin $1, \mathbf{F}=$ globulin 2 , and $G=$ glutelin 2 . All images are at 130,000× magnification. 
oxidation. The albumin fraction contained less tyrosine than globulins, suggesting that oxidation of tyrosine may play an insignificant role in protein aggregation.

\section{THERMAL GRAVIMETRIC ANALYSIS}

TGA and derivative thermogravimetry (DTG) curves are presented in figure 7 as the weight loss (\%) and derivative weight loss rate $\left(\% \mathrm{~min}^{-1}\right)$, respectively, and as a function of sample temperature in the range of $25^{\circ} \mathrm{C}$ to $900^{\circ} \mathrm{C}$. The degradation of camelina protein fractions underwent two to four stages with different final mass of retention residues. Noncombustible residues are inorganic materials. Albumin showed four stages (three stages for globulin 0 and glutelin 0,1 , and 2, and two stages for globulin 1 and 2), indicating that albumin had a more complicated composition.

In the first stage, the mass of the protein samples decreased by $3 \%$ to $7.5 \%$ as the temperature increased from $25^{\circ} \mathrm{C}$ to around $150^{\circ} \mathrm{C}$, which could be ascribed to evaporation of both the free water and physically absorbed water in the samples. In this stage, the maximum mass loss occurred to albumin, indicating that albumin had the highest water absorption ability, possibly because albumin had the most hydrophilic nature (about $73 \%$ of hydrophilic amino acid, table 2) of the camelina protein fractions. Hydrophilic amino acid side-chains are known to be charged or polar and capable of attracting water molecules involved in the for-
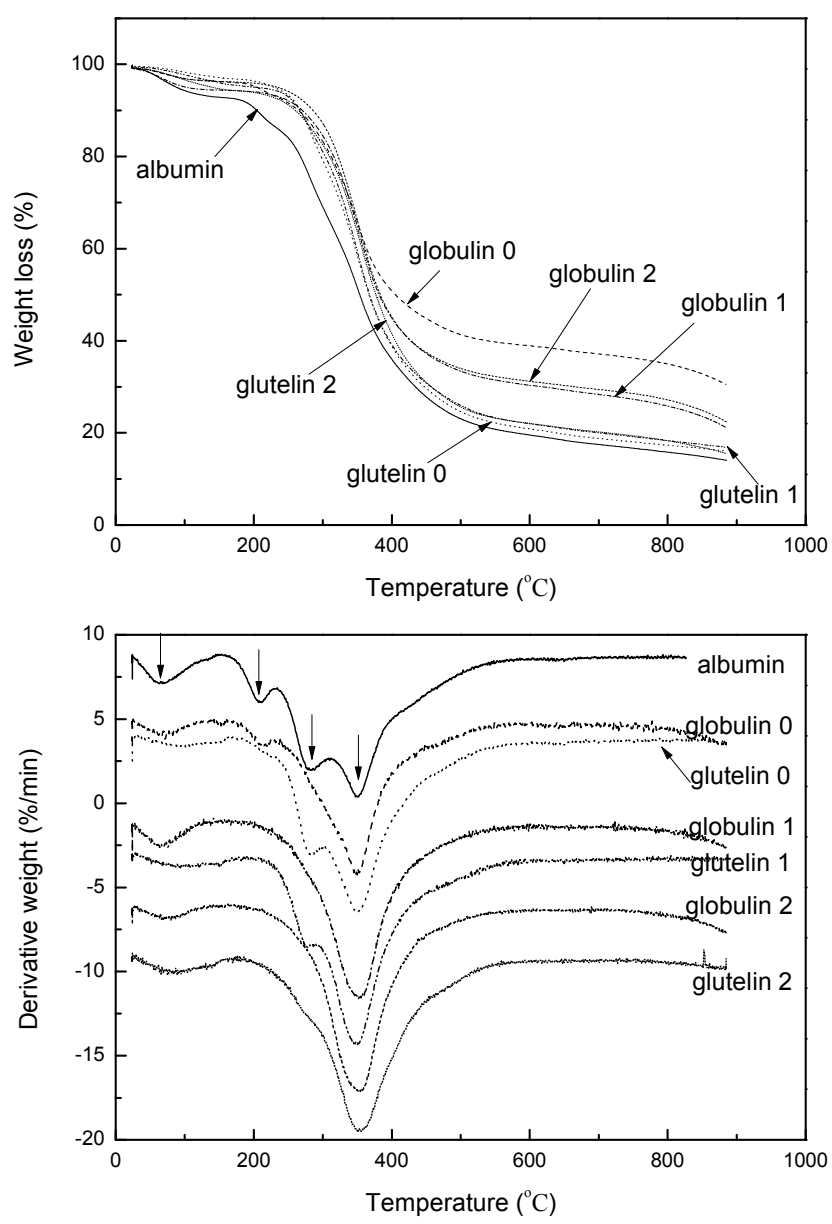

Figure 7. Thermogravimetric and derivative thermogravimetric curves of camelina proteins. mation of hydrogen bonds. They are also predominantly found on the exterior surfaces of proteins (King, 2011). The second peak at $206.4^{\circ} \mathrm{C}$ for albumin was probably due to the degradation of water-soluble gum, which coexisted with albumin, as mentioned previously. Similarly, peaks with similar temperatures were also observed for the globulin 0 and glutelin 0 fractions extracted without the degumming procedure. In addition, the larger mass loss at $206.4^{\circ} \mathrm{C}$ for globulin 0 indicated a high content of gum, which is consistent with the low protein purity of globulin 0 , as shown in table 1 . Notably, peaks were detected at around $280^{\circ} \mathrm{C}$ to $290^{\circ} \mathrm{C}$ for all glutelin reactions, probably due to thermal breakage of weak non-covalent or covalent bonds.

The major peaks observed around $356^{\circ} \mathrm{C}$ for all the protein fractions are believed to be protein degradation, a process that involves breakage of intermolecular and intramolecular hydrogen bonds and electrostatic bonds, decomposition of protein side-chains, and rupture of weak bonds such as $\mathrm{C}-\mathrm{N}, \mathrm{C}(\mathrm{O})-\mathrm{NH}, \mathrm{C}(\mathrm{O})-\mathrm{NH}_{2}$, and $\mathrm{NH}_{2}$ (Mo et al., 2011). Glutelins had a lower degradation peak (around $348^{\circ} \mathrm{C}$ ) than globulins (around $352^{\circ} \mathrm{C}$ ), with the exception of glutelin $2\left(356^{\circ} \mathrm{C}\right)$. As explained previously, $\mathrm{NaCl}$ increased the ionic strength and resulted in enhanced hydrophobic interactions, thus improving the thermal stability of globulins and glutelin 2 in terms of the higher degradation peak. Molecular conformation can also affect the protein degradation rate. Again, the globulin fraction had higher mass retention at approximately $350^{\circ} \mathrm{C}(64.66 \%$ to $66.42 \%)$, which also suggests a higher thermal stability for globulin.

\section{CONCLUSIONS}

Physicochemical properties of camelina protein fractions, including solubility and precipitation abilities, amino acid profiles, molecular weight distributions, secondary structures, morphological properties, and thermal properties, varied in different protein fractions. The MS-pH of albumin, globulin, and glutelin were found at $\mathrm{pH} 3.0,3.0$, and 4.5 to 5.0, respectively. S0 extracted the highest amounts of protein isolates but the lowest protein purities due to the presence of gum. S1 was more effective than S0 and S2 in terms of protein recovery and purities. Essential amino acids accounted for approximately $40 \%$ of total amino acids, and essential amino acid profiles met or exceeded WHO standards for children over one year old and adults. Camelina proteins had $26 \%$ to $28 \%$ hydrophobic amino acids, which is lower than canola, soy, and sorghum proteins. Glutelins exhibited higher $\alpha$-helix to $\beta$-sheet ratios (1.03 to 1.05$)$ than the globulin fractions $(0.91$ to 1.00$)$ and albumin (0.84). Studying the isolation process of camelina protein fractions and the proteins' physicochemical properties is vital to understanding camelina's unique functionality and thus exploring its applications in food and industrial areas such as biodegradable adhesives, plastics, or films.

\section{ACKNOWLEDGEMENTS}

This project was funded by the USDA-NIFA Biomass Research and Development Initiative Competitive Grants Program (BRDI) (Contract No. 2012-10006-20230). 


\section{REFERENCES}

Ayad, A. (2010). Characterization and properties of flaxseed protein fractions. PhD diss. Montreal, Quebec, Canada: McGill University, Department of Food Science and Agricultural Chemistry.

Badifu, G., \& Akubor, P. (2001). Influence of pH and sodium chloride on selected functional and physical properties of African breadfruit (Treculia africana Decne) kernel flour. Plant Foods for Human Nutr., 56(2), 105-115.

Bean, S. R., Ioerger, B. P., Park, S. H., \& Singh, H. (2006). Interaction between sorghum protein extraction and precipitation conditions on yield, purity, and composition of purified protein fractions. Cereal Chem., 83(1), 99-107. http://dx.doi.org/10.1094/CC-83-0099.

Betts, M., \& Russell, R. (2003). Amino acid properties and consequences of substitutions. In Bioinformatics for Geneticists, 290-316. M. Barnes, \& I. Gray, eds. New York, N.Y.: John Wiley and Sons.

Bhatty, R., \& Finlayson, A. (1973). Extraction of nonprotein nitrogen from oilseed meals with different solvents. Cereal Chem., 50(3), 329-335.

Brosnan, J., \& Brosnan, M. (2006). The sulfur-containing amino acids: An overview. J. Nutr., 136(6), 1636s-1640s.

Budin, J., Breene, W., \& Putnam, D. (1995). Some compositional properties of camelina (Camelina sativa L. Crantz) seeds and oils. J. American Oil Chem. Soc., 72(3), 309-315. http://dx.doi.org/10.1007/BF02541088.

Carbonaro, M., Cappelloni, M., Nicoli, S., Lucarini, M., \& Carnovale, E. (1997). Solubility-digestibility relationship of legume proteins. J. Agric. Food Chem., 45(9), 3387-3394. http://dx.doi.org/10.1021/jf970070y.

Cromwell, M., Hilario, E., \& Jacobson, F. (2006). Protein aggregation and bioprocessing. AAPS J., 8(3), E572-E579. http://dx.doi.org/10.1208/aapsj080366.

Grady, K., \& Nleya, T. (2010). Camelina production. Extension Extra 8167. Brookings, S.D.: South Dakota State University, College of Agriculture and Biological Sciences. Retrieved from http://pubstorage.sdstate.edu/AgBio_Publications/articles/ ExEx8167.pdf.

Guillén, M., \& Cabo, N. (1997). Characterization of oils and lard by Fourier transform infrared spectroscopy: Relationships between composition and frequency of concrete bands in the fingerprint region. J. American Oil Chem. Soc., 74(10), 1281-1286. http://dx.doi.org/10.1007/s11746-997-0058-4.

Jackson, M., \& Mantsch, H. (1995). The use and misuse of FTIR spectroscopy in the determination of protein structure. Crit. Rev. Biochem. Molec. Biol., 30(2), 95-120. http://dx.doi.org/ 10.3109/10409239509085140.

Khorasani, G., Sauer, W. C., Ozimek, L., \& Kennelly, J. J. (1990). Digestion of soybean meal and canola meal protein and amino acids in the digestive tract of young ruminants. J. Animal Sci., 68(10), 3421-3428.

King, M. W. (2011). Chemical nature of the amino acids. The Medical Biochemistry Page. Retrieved from http://themedicalbiochemistrypage.org/amino-acids.html.

Kong, J., \& Yu, S. (2007). Fourier transform infrared spectroscopic analysis of protein secondary structures. Acta Biochim. Biophys. Sinica, 39(8), 549-559. http://dx.doi.org/10.1111/j.17457270.2007.00320.x.
Li, N., Qi, G., Sun, S. X., Stamm, M., \& Wang, D. (2011a). Physicochemical properties and adhesion performance of canola protein modified with sodium bisulfite. J. American Oil Chem. Soc., 89(5), 897-908. http://dx.doi.org/10.1007/s11746-0111977-7.

Li, N., Wang, Y., Tilley, M., Bean, S. R., Wu, X., Sun, S. X., \& Wang, D. (2011b). Adhesive performance of sorghum protein extracted from sorghum DDGS and flour. J. Polymer Environ., 19(3), 755-765. http://dx.doi.org/10.1007/s10924-011-0305-5.

Makkar, H., Grancis, G., \& Becker, K. (2008). Protein concentrate from Jatropha curcas screw-pressed seed cake and toxic and antinutritional factors in protein concentrate. J. Sci. Food Agric., 88(9), 1542-1548. http://dx.doi.org/10.1002/jsfa.3248.

Manamperi, W. A., Chang, S. K. C., Wiesenborn, D. P., \& Pryor, S. W. (2008). Alteration of Osborn sequence extraction for isolation of canola proteins. ASABE Paper No. 083924. St. Joseph, Mich.: ASABE.

Masci, S., D’Ovidio, R., Lafiandra, D., \& Kasarda, D. D. (1998). Characterization of a low-molecular-weight glutenin subunit gene from bread wheat and the corresponding protein that represents a major subunit of the glutenin polymer. Plant Physiol., 118(4), 1147-1158. http://dx.doi.org/ 10.1104/pp.118.4.1147.

Mo, X., D., W., \& Sun, S. X. (2011). Physicochemical properties of and subunits isolated from soybean -conglycinin. J. Agric. Food Chem., 59(4), 1217-1222. http://dx.doi.org/10.1021/jf102903b.

Nielsen, H. C., Paulis, J. W., James, C., \& Wall, J. S. (1970). Extraction and structure studies on corn glutelin proteins. Cereal Chem., 47(5), 501-512.

Osborne, T. (1924). The Vegetable Proteins. 2nd ed. London, U.K.: Longmans.

Sampath, A. (2009). Chemical characterization of camelina seed oil. MS thesis. New Brunswick, N.J.: Rutgers, The State University of New Jersey, Graduate School-New Brunswick.

Shonnard, D., Williams, L., \& Kalnes, T. (2010). Camelina-derived jet fuel and diesel: Sustainable advanced biofuels. Environ. Prog. Sustain. Energy., 29(3). http://dx.doi.org/10.1002/ ep.10461.

Tecson, E. M. S., Esmama, B. V., Lontok, L. P., \& Juliano, B. O. (1971). Studies on the extraction and composition of rice endosperm glutelin and prolamin. Cereal Chem., 48(2), 168181.

Wetzel, D., Srivarin, P., \& Finney, J. R. (2003). Revealing protein infrared spectral detail in a heterogeneous matrix dominated by starch. Vibrational Spectrosc., 31(1), 109-114. http://dx.doi.org/10.1016/S0924-2031(02)00100-5.

WHO. (2007). Protein and amino acid requirements in human nutrition. WHO Technical Report Series 935. Geneva, Switzerland: World Health Organization. Retrieved from http://whqlibdoc.who.int/trs/who_trs_935_eng.pdf.

Yu, P., McKinnon, J. J., Soita, H. W., Christensen, C. R., \& Christensen, D. A. (2005). Use of synchrotron-based FTIR microspectroscopy to determine protein secondary structures of raw and heat-treated brown and golden flax seeds: A novel approach. Canadian J. Animal Sci., 85(4), 437-448. http://dx.doi.org/10.4141/A05-004.

Zubr, J. (2002). Dietary fatty acids and amino acids of Camelina sativa seed. J. Food Qual., 26(6), 451-462. http://dx.doi.org/10.1111/j.1745-4557.2003.tb00260.x. 